\title{
System Performance and Pollution Emission of Biomass Gas Co-Firing in a Coal-Fired Boiler
}

\author{
Sikandar Abid, Xiaotao Zhang, Weidong Zhang, Haoliang Mu, Chengyu Zhang, Aijun Wang* \\ School of Electric Power, North China University of Water Resources and Electric Power, Zhengzhou, China \\ Email: *wangaijun@ncwu.edu.cn
}

How to cite this paper: Abid, S., Zhang, X.T., Zhang, W.D., Mu, H.L., Zhang, C.Y. and Wang, A.J. (2020) System Performance and Pollution Emission of Biomass Gas Co-Firing in a Coal-Fired Boiler. Journal of Power and Energy Engineering, 8, 18-25. https://doi.org/10.4236/jpee.2020.810002

Received: September 10, 2020

Accepted: October 16, 2020

Published: October 19, 2020

Copyright $\odot 2020$ by author(s) and Scientific Research Publishing Inc. This work is licensed under the Creative Commons Attribution International License (CC BY 4.0).

http://creativecommons.org/licenses/by/4.0/

\begin{abstract}
To reduce greenhouse gases emission and increase the renewable energy utilization portion in the world, the biomass gasification coupled with a coal-fired boiler power generation system is studied. It is a challenge to achieve optimum performance for the coupled system. The models of biomass gasification coupled with co-firing of coal in a boiler have been established. A comparative study of three kinds of biomass (Food Rubbish, Straw and Wood Pellets) has been done. The syngas produced in a $10 \mathrm{t} / \mathrm{h}$ gasifier is fed to a 330 MWe coal-fired boiler for co-combustion, and the co-firing performances have been compared with pure coal combustion case under the conditions of constant boiler load. Results show that co-firing decreases the furnace combustion temperature and raises the flue gas temperature for Food Rubbish and Straw, while, flue gases temperature decrease in case of Wood Pellets. At the same time $\mathrm{NO}_{\mathrm{x}}$ and $\mathrm{SO}_{\mathrm{x}}$ emissions have reduced. The system efficiencies at constant load for Food Rubbish, Straw and Wood Pellets are $83.25 \%$, $83.88 \%$ and $82.56 \%$ when the optimum conditions of gasification and co-firing process are guaranteed.
\end{abstract}

\section{Keywords}

Biomass Gasification, Coal-Fired Boiler, System Efficiency, Optimal Air to Biomass Ratio

\section{Introduction}

Nowadays energy generation is the heart of most critical, economic, environmental, and development issues of the world. Challenges are faced by the global community and national governments due to energy security, climate change, health impacts, and poverty. Shifting toward green energy production is sup- 
posed to play a critical role in solving some of the most prominent contemporary challenges the world is facing at present [1]. As power demand increases, power generation increases, which results in increased emission of $\mathrm{NO}_{\mathrm{x}}, \mathrm{SO}_{\mathrm{x}}$ and $\mathrm{CO}_{2}$. The largest emission source of these pollutants comes from coal-fired power plants [2]. These pollutants cause various environmentally harmful effects such as acid rain, ozone depletion and urban smog [3] [4]. Biomass gasification coupled with a coal-fired power plant is one of the solutions to the problems. In Pakistan, there produce 82 million tons of biomass. It is best to use this biomass in power generation as it reduces both fossil fuel consumption and mitigates climate change [5]. Biomass gasification is a process for converting carbonaceous material to a combustible or synthetic gas [6]. The solid biomass is converted into a gaseous product that can be handled with maximum convenience, and low cost and readily be purified to a clean fuel [7]. It is a complex process and the operational parameters in the gasification process play an important role in improving the quality and quantity of syngas [8]. As compared to the pure coal case, co-firing of syngas results in decrease of furnace combustion temperature and the increase of flue gas temperature and volume flow rate. Thus, boiler efficiency slightly decreases; however, emissions of $\mathrm{NO}_{\mathrm{x}}$ and $\mathrm{SO}_{\mathrm{x}}$ decline also.

Aspen Plus is a widely used process simulation software nowadays and can simulate the gasification process of biomass fluidized bed gasifier and the co-firing process of bio-gas with the coal-fired boiler. Meanwhile, the simulation results were compared with test data and the rationality of the model was verified successfully [9]. Based on chemical balance and phase equilibrium, a fixed bed gasifier model was developed using Aspen Plus. Study shows that the model can be used to predict the syngas component at optimized working conditions [10].

Biomass gasification coupled with a coal-fired power plant is more useful than directly co-firing. The co-firing of most kinds of biomass may reduce the boiler efficiency. Wet wood chip for biomass gasification was studied and gasification efficiency increased for biomass with $20 \%$ [11]. It solves boiler fouling and corrosion problems up to some extent. As biomass ash is removed before syngas is brought in a furnace, ash characteristics of the boiler remain the same [12].

In this work, the operation processes of the biomass gasification coupled with a coal-fired boiler system were simulated. Straw, Food Rubbish and Wood Pellet are employed as feedstock at gasifier. They were gasified at the air to biomass ratio varying from 0.6 to 2.4 . The comparative study between three cases is done to find the best of them. The effects of the air to biomass ratio on bio-gas compositions, bio-gas low calorific value, biomass gasification efficiency, and the influences of excess air ratio on the furnace combustion temperature, flue gas compositions, boiler efficiency and the system efficiency of biomass utilization have been studied. The findings will give a reference to apply the co-firing technology in coal-fired power plants.

\section{The Basic Theory of Coupled System}

The operational performance of biomass gasification coupled with coal-fired 
boiler directly depends upon the biomass gasification and co-firing of biomass and coal. The system includes one coal-fired boiler and one biomass gasifier. The block diagram of biomass gasification coupled with the coal-fired boiler is shown as Figure 1.

Three kinds of biomass are studied, which are Food Rubbish, Straw and Wood Pellets. They were gasified in a gasifier, whose capacity is constant and its mass flow rate is $10 \mathrm{t} / \mathrm{h}$. The air is used as a gasifying agent. The cooling temperature of syngas after it leaves cooler is $450^{\circ} \mathrm{C}$. Then obtained syngas from each case was entered the coal-fired boiler for co-firing with coal. Then flue gases were passed through the heating surface of the boiler. The air leakage is considered at the tail heating surface of the boiler. The boiler is a subcritical pressure and natural circulation boiler with a maximum capacity of $330 \mathrm{MW}$ production. Three different co-firing cases have been studied at that of $100 \%$ Boiler Rated Load (BRL).

\section{Fuel Analysis}

The proximate analysis, Ultimate analysis and Lower heating value of the sub-bituminous coal, Food Rubbish, Straw, and Wood Pellets are shown in Table 1 .

\section{System Modeling}

\subsection{Biomass Gasification and Syngas Cooling Process}

The biomass gasification is composed of four sequential step processes which include biomass pyrolysis, biomass gasification, separation of syngas and biomass ash and syngas cooling, as shown in Figure 2.

The feed biomass is gasified as a non-conventional stream. The biomass stream is passed to the DECOMP block where biomass pyrolysis is done to get conventional components such as carbon $(\mathrm{C})$, sulfur $(\mathrm{S})$, oxygen $\left(\mathrm{O}_{2}\right)$, hydrogen $\left(\mathrm{H}_{2}\right)$, water $\left(\mathrm{H}_{2} \mathrm{O}\right)$, nitrogen $\left(\mathrm{N}_{2}\right)$ and ASH. Then block GASIFY is used for biomass gasification. It is used to calculate the chemical and phase equilibrium of

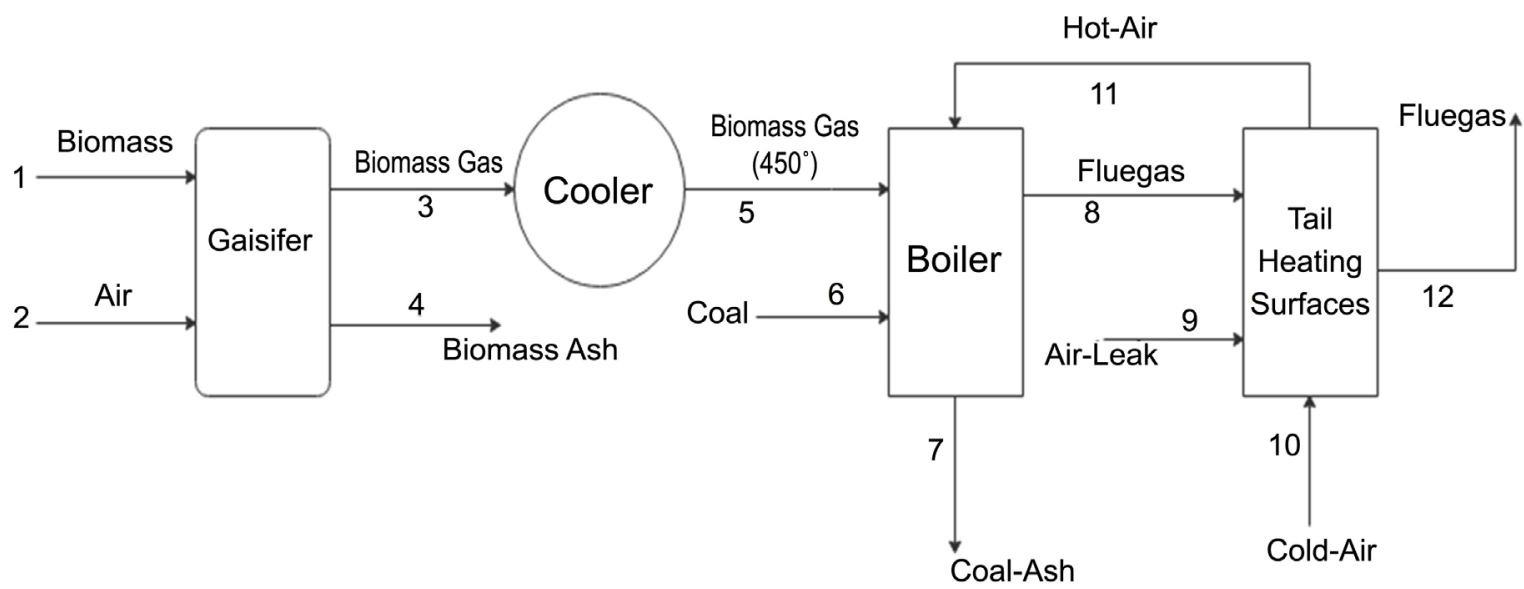

Figure 1. The block diagram of biomass gasification coupled with the coal-fired boiler system. 


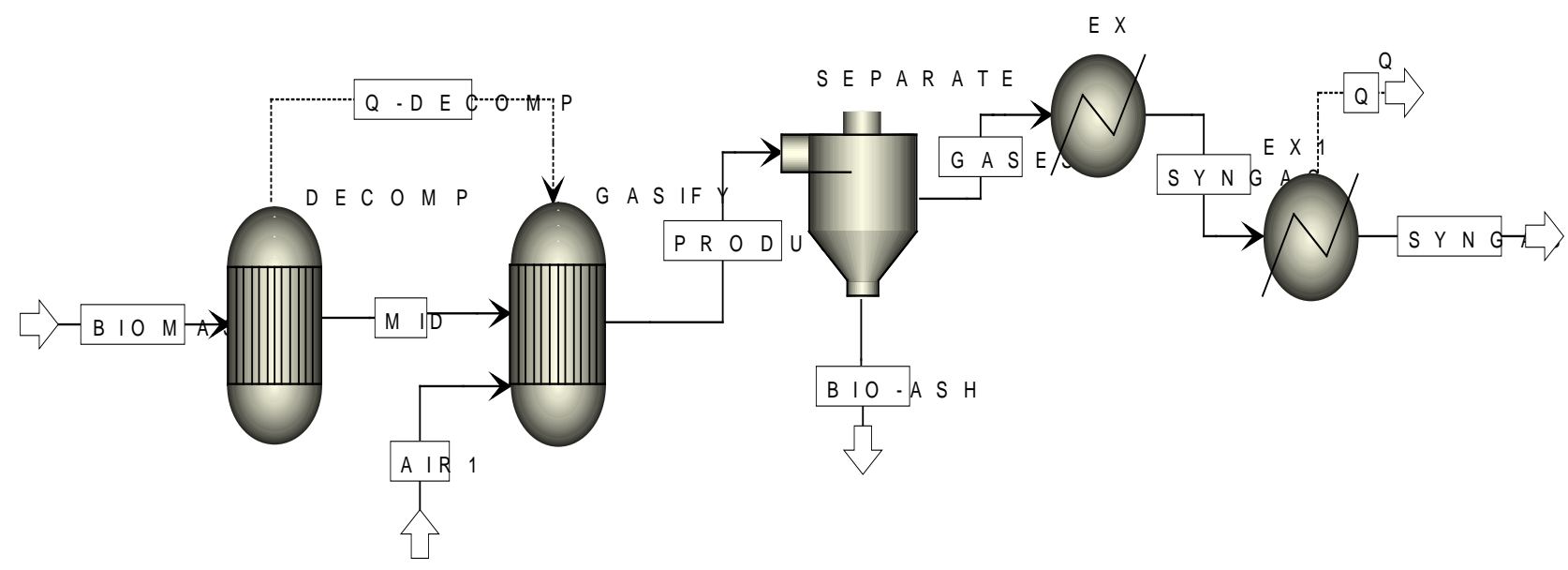

Figure 2. The simulation flow chart of biomass gasification and syngas cooling process.

Table 1. Proximate, ultimate analysis of fuel (Received basis) [13] [14].

\begin{tabular}{ccccccccccc}
\hline \multirow{2}{*}{ Fuel } & \multicolumn{9}{c}{ Proximate analysis $(\mathrm{wt} \%)$} & \multicolumn{5}{c}{ Ultimate analysis (wt\%) } & \multirow{2}{*}{ Low calorific } \\
\cline { 2 - 8 } & $\mathrm{FC}$ & $\mathrm{V}$ & $\mathrm{A}$ & $\mathrm{M}$ & $\mathrm{C}$ & $\mathrm{H}$ & $\mathrm{O}$ & $\mathrm{N}$ & $\mathrm{S}$ & value/(kJ/kg) \\
\hline Sub-Bituminous Coal & 25.12 & 41.60 & 7.03 & 26.25 & 48.69 & 4.68 & 11.34 & 1.30 & 0.71 & 19685.81 \\
Food Rubbish & 14.62 & 51.40 & 4.78 & 29.20 & 40.40 & 6.18 & 16.54 & 2.77 & 0.13 & 17430.90 \\
Straw & 17.75 & 71.45 & 5.93 & 4.87 & 44.55 & 5.33 & 38.46 & 0.74 & 0.12 & 16293.00 \\
Wood Pellets & 12.72 & 71.96 & 1.77 & 13.55 & 40.05 & 4.65 & 39.97 & 0.01 & 0.00 & 13675.90 \\
\hline
\end{tabular}

the system by minimizing the Gibbs free energy. Its main purpose is to gasify solid biomass into a gas-solid stream PRODUCT. The block SEPARATE is used to separate biomass ash from syngas to get gaseous stream GASES. Then this gaseous stream enters the heat exchanger EX block where syngas is cooled to $450^{\circ} \mathrm{C}$. Then this cooled stream SYNGAS, is the syngas entered into the boiler.

\subsection{Co-Firing Process and Heat Exchange Process in the Tail Flue}

In a co-firing process coal pyrolysis, co-firing of syngas with coal and heat exchange process in the tail are carried out. Latter this process is split into three further steps: separation of coal ash and flue gases, air leakage and heat exchange in tail flue gases channel, as shown in Figure 3.

Coal is pyrolyzed in the block DECOMP 1 into the products such as $\mathrm{C}, \mathrm{S}, \mathrm{O}_{2}$, $\mathrm{H}_{2}, \mathrm{H}_{2} \mathrm{O}, \mathrm{N}_{2}$ and $\mathrm{ASH}$. Then preheated air, syngas and coal products are co-fired in block BURN. Coal ash is separated from flue gases by the block SEP to obtain gaseous stream GAS. Then the stream GAS is introduced in the tail flue. Meanwhile, the model of the heat exchange process of tail heating surfaces of the boiler is established. It has the heat exchanger block (HEATER type) and two mixer block (MIXER type). The heat exchanger blocks HEATER is used to simulate the process in super-heater, re-heater, and economizer. The heat exchanger block PRE-FLUE and PRE-AIR are used to simulate the cooling process of the flue gases side and heating process of the air side respectively in air pre-heater. 


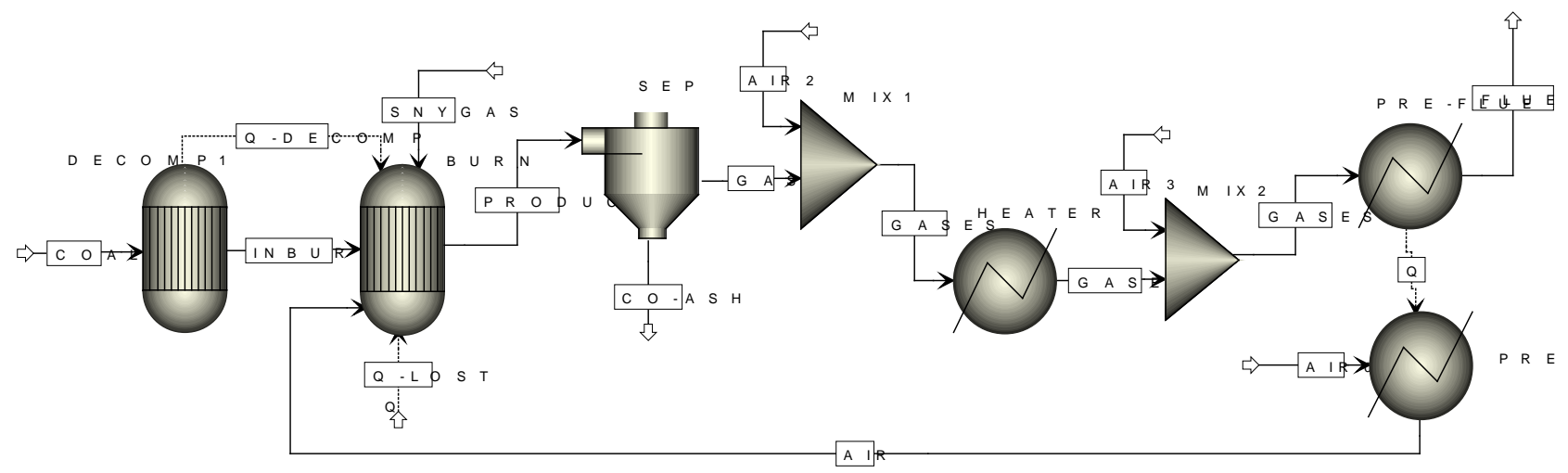

Figure 3. The simulation flow chart of co-firing and heat exchange in tail fuel.

\section{Results and Discussions}

\subsection{Biomass Gasification Process Performance Index}

The maximum heat efficiency can only be obtained at optimum air to biomass ratio. The gasification temperature at optimal air to biomass ratio of Food Rubbish, Straw and Wood Pellets is $650^{\circ} \mathrm{C}, 703^{\circ} \mathrm{C}$ and $652^{\circ} \mathrm{C}$ the syngas characteristics parameters obtained at optimum air to biomass ratio is shown in Table 2.

\subsection{The Basic Parameters and Boiler Efficiency of the Co-Firing Process}

Syngas co-firing ratio, coal consumption mass flow rate, and the theoretical air mass flow rate were obtained, as shown in Table 3.

As boiler load is constant, the coal consumption mass flow rate and theoretical air mass flow rate decrease in co-firing cases as compared to the pure coal case. In Food Rubbish there is a 5.06\% decrease in coal consumption while $4.76 \%$ and $4.15 \%$ decrease in the case of Straw and Wood Pellets. The theoretical air mass flow rate in Food Rubbish case decreased by $1.60 \%$ while in the case of Straw and Wood Pellets it decreased $1.53 \%$ and $1.49 \%$ respectively.

\subsection{Performance of the Coupled System}

The highest operating efficiency of the boiler, boiler operation parameters, flue gas components and characteristics at air pre-heater outlet and system efficiency are shown in Table 4.

Furnace combustion temperature in pure coal case is at $1345.81^{\circ} \mathrm{C}$ while it decreases slightly in co-firing cases, Food Rubbish gas at $1340.87^{\circ} \mathrm{C}$, Straw gas at $1342.83^{\circ} \mathrm{C}$, and Wood Pellets gas at $1340.23^{\circ} \mathrm{C}$. Flue gas temperature increases in the case of Food Rubbish gas and Straw gas co-firing but decreases in the case of Wood Pellets gas co-firing, as compared to pure coal case. There are slight oscillations in the flue gases flow rate. Boiler efficiency slightly decreases in co-firing cases. The volume fraction of the main components of flue gases $\mathrm{H}_{2} \mathrm{O}$ and $\mathrm{CO}_{2}$ increases while $\mathrm{N}_{2}$ and $\mathrm{O}_{2}$ decreases in co-firing cases. The volume fraction of pollutant components nitrogen oxide $(\mathrm{NO})$, nitrous oxide $\left(\mathrm{N}_{2} \mathrm{O}\right)$, nitrogen dioxide $\left(\mathrm{NO}_{2}\right)$, sulfur dioxide $\left(\mathrm{SO}_{2}\right)$, and sulfur trioxide $\left(\mathrm{SO}_{3}\right)$ decreases. 
Table 2. Optimal syngas components and gasification characteristic parameters.

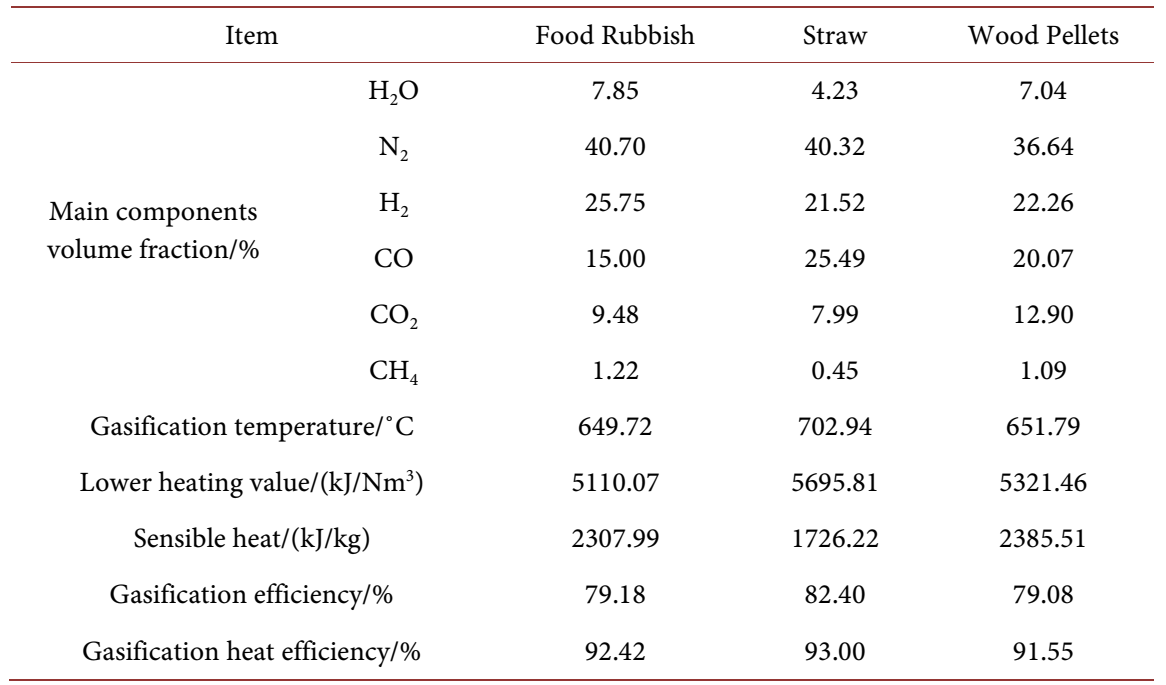

Table 3. Mass flow rate of coal consumption and theoretical air mass.

\begin{tabular}{ccccc}
\hline Item & $\begin{array}{c}\text { Pure coal } \\
\text { (sub-bituminous coal) }\end{array}$ & Food Rubbish & Straw & Wood Pellets \\
\hline $\begin{array}{c}\text { Co-firing ratio (\%) } \\
\begin{array}{c}\text { Coal consumption } \\
\text { mass flow rate }(\mathrm{kg} / \mathrm{h})\end{array}\end{array}$ & - & 5.06 & 4.76 & 4.15 \\
\begin{tabular}{c} 
Theoretical air mass flowrate $(\mathrm{kg} / \mathrm{h})$ \\
\hline
\end{tabular} & 163004.26 & 154748.35 & 155239.14 & 156239.28 \\
\hline
\end{tabular}

Table 4. Flue gas components, flue gases characteristic and coupled system performance.

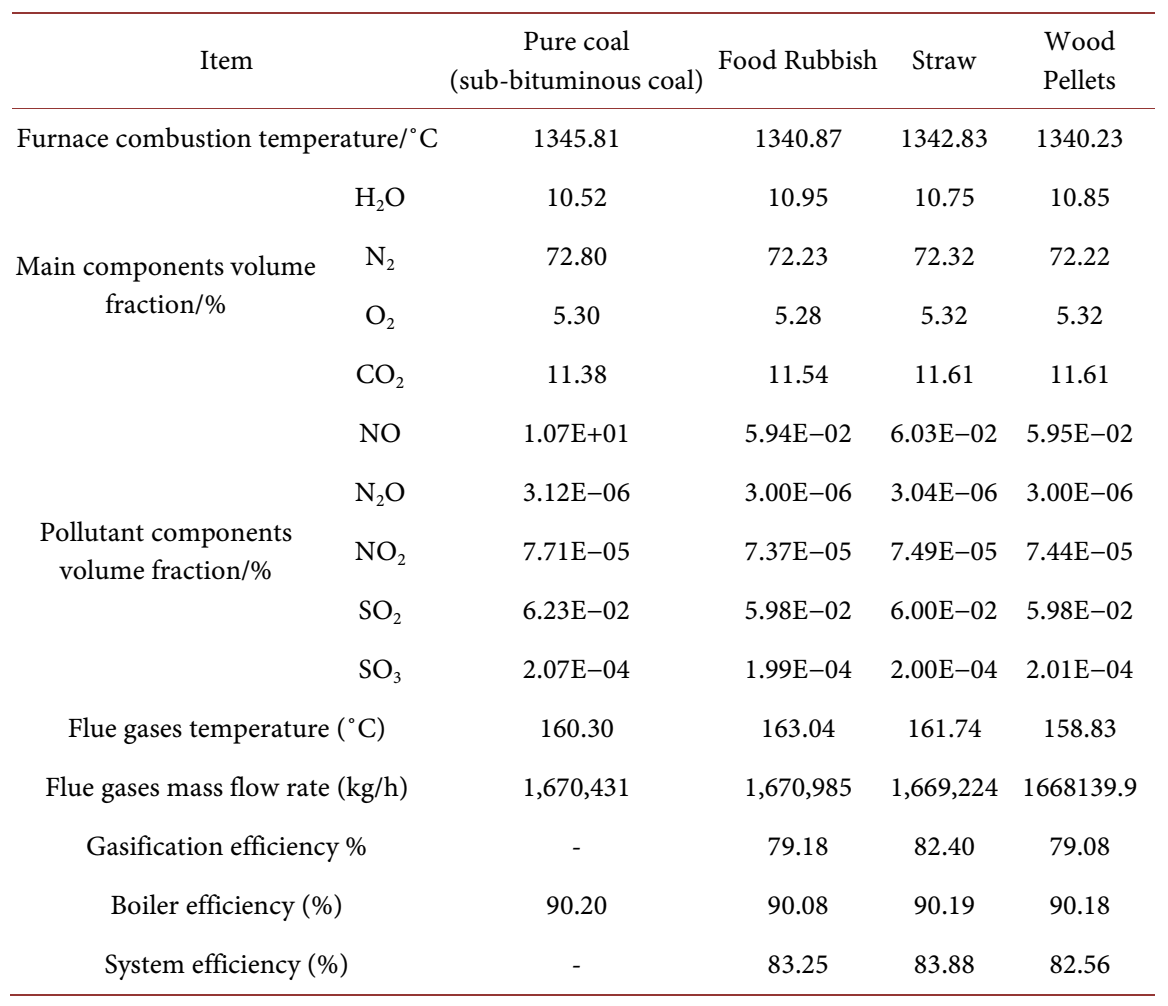


The reason behind the reduction of $\mathrm{NO}_{\mathrm{x}}$ and $\mathrm{SO}_{\mathrm{x}}$ in flue gas is that the presence of reductive gases carbon monoxide $(\mathrm{CO}), \mathrm{H}_{2}$, and methane $\left(\mathrm{CH}_{4}\right)$ in syngas. It reduces $\mathrm{NO}_{\mathrm{x}}$ to $\mathrm{N}_{2}$ along with the generation of $\mathrm{H}_{2} \mathrm{O}$ and $\mathrm{CO}_{2}$ under reducing temperature. That is why the $\mathrm{H}_{2} \mathrm{O}$ and $\mathrm{CO}_{2}$ content increase in flue gases after co-firing. The decrease in combustion temperature and the presence of $\mathrm{N}$ and $\mathrm{S}$ in biomass fuel is the most important factor in the reduction of volume fraction of $\mathrm{NO}_{\mathrm{x}}$ and $\mathrm{SO}_{\mathrm{x}}$ [15] [16] [17] [18].

System efficiency is $83.25 \%$ in the case of Food Rubbish gas co-firing, $83.88 \%$ in the case of Straw gas and $82.56 \%$ in Wood Pellets gas case.

\section{Conclusion}

A 330 MWe boiler and a $10 \mathrm{t} / \mathrm{h}$ gasifier are employed to simulate the co-firing system performance and pollution emissions. It found the syngas from straw had maximum boiler efficiency as compared to that of Food Rubbish and Wood Pellets in co-firing cases, and the co-firing of straw syngas had a maximum system efficiency of $83.88 \%$ while Food Rubbish and Wood Pellets were $83.25 \%$ and $82.56 \%$ respectively. As compared to pure coal case it is observed that in co-firing cases the furnace combustion temperature decreased and the flue gases temperature increased, but in case of Wood Pellets the flue gases temperature decreased. The volume flow rate also increased in the case of Food Rubbish and Straw but decreased in the case of Wood Pellets. Boiler efficiency and emission of $\mathrm{NO}$ and $\mathrm{SO}_{2}$ reduced in the case of co-firing.

\section{Conflicts of Interest}

The authors declare no conflicts of interest regarding the publication of this paper.

\section{References}

[1] European Commission (2007) World Energy Technology Outlook to 2050. Brussels.

[2] Munir, S., Nimmo, W. and Gibbs, B.M. (2011) The Effect of Air Staged Co-Combustion of Pulverized Coal and Biomass Blend on $\mathrm{NO}_{x}$ Emission and Combustion Efficiency. Fuel, 90, 126-135. https://doi.org/10.1016/j.fuel.2010.07.052

[3] Houshfar, E., Khalil, R.A., LØvås, T. and Skreiberg, Ø. (2012) Enhanced $\mathrm{NO}_{x}$ Reduction by Combined Staged Air and Flue Gas Recirculation in Biomass Grate Combustion. Energy Fuels, 26, 3003-3011. https://doi.org/10.1021/ef300199g

[4] Bowman, C.T. (1992) Control of Combustion-Generated Nitrogen Oxide Emission Technology Driven by Regulation Pro Combustion. Science Direct, 24, 859-879. https://doi.org/10.1016/S0082-0784(06)80104-9

[5] Balat, M. and Ayar, G. (2006) Biomass Energy in the World, Use of Biomass and Potential Trends. Energy Sources, 27, 931-940. https://doi.org/10.1080/00908310490449045

[6] Rezaiyan, J. and Cheremisinoff, N.P. (2005) Gasification Technologies A Primer for Engineers and Scientists. Taylor \& Francis, Abingdon-on-Thames. https://doi.org/10.1201/9781420028140

[7] Doherty, W., Reynolds, A. and Kennedy, D. (2009) The Effect of Air Preheating in a 
Biomass CFB Gasifier Using Aspen plus Simulation. Biomass \& Bioenergy, 33, 1158-1167. https://doi.org/10.1016/j.biombioe.2009.05.004

[8] Omar, M.M., Munir, A., Ahmad, M. and Tanveer, A. (2018) Downdraft Gasifier Structure and Process Improvement for High Quality and Quantity Producer Gas Production. Journal of the Energy Institute, 91, 1034-1044.

https://doi.org/10.1016/j.joei.2017.07.005

[9] Kaushal, P. and Tyagi, R. (2017) Advanced Simulation of Biomass Gasification in a Fluidized Bed Reactor Using ASPEN plus. Renewable Energy, 101, 629-636. https://doi.org/10.1016/j.renene.2016.09.011

[10] Begum, S., Rasul, M.G. and Akbar, D. (2014) A Numerical Investigation of Municipal Waste Gasification Using Aspen plus. Procedia Engineering, 90, 710-717. https://doi.org/10.1016/j.proeng.2014.11.800

[11] Kirsanovs, V. and Zandeckis, A. (2015) Investigation of Biomass Gasification Process with Torrefaction Using Equilibrium Model. Energy Procedia, 72, 329-336. https://doi.org/10.1016/j.egypro.2015.06.048

[12] Dong, C.Q., Yang, Y.P., Yang, R. and Zhang, J.J. (2010) Numerical Modeling of the Gasification Based Biomass Co-Firing in a 600 MW Pulverized Coal Boiler. Applied Energy, 87, 2834-2838. https://doi.org/10.1016/j.apenergy.2009.05.033

[13] Zhang, X.T., Li, K.Y., Zhang, C. and Wang, A.J. (2020) Performance Analysis of Biomass Gasification Coupled with a Coal-Fired Boiler System at Various Loads. Waste Management, 105, 84-91. https://doi.org/10.1016/j.wasman.2020.01.039

[14] Sarwar, A., Khan, M.N. and Azhar, K.F. (2012) Kinetic Studies of Pyrolysis and Combustion of Thar Coal by Thermogravimetry and Chemometric Data Analysis. Journal of Thermal Analysis and Calorimetry, 109, 97-103. https://doi.org/10.1007/s10973-011-1725-0

[15] Hu, X.Y., Wang, T., Dong, Z.H., Zhang, H.F. and Dong, C.Q. (2012) Research on the Gas Re-Burning in a Circulating Fludized Bed (CFB) System Integrated with Biomass Gasification. Energies, 5, 3167-3177. https://doi.org/10.3390/en5093167

[16] Zhang, X.T., Li, K.Y., Zhao, W. and Huang, Y. (2018) Simulation on Operation Efficiency and Pollutant Emission of Coal-Fired Boiler with Bio-Gas Co-Firing. Transaction of the Chinese Society of Agricultural Engineering, 34, 194-202.

[17] Shu, Y., Zhang, F., Wang, H.C., Zhu, J.W., Tian, G., Zhang, C., Cui, Y.T. and Huang, J.Y. (2015) An Experimental Study of NO Reduction by Biomass Re-Burning and the Characterization of Its Pyrolysis Gases. Fuel, 139, 321-327. https://doi.org/10.1016/j.fuel.2014.08.071

[18] Bui, M., Fajardy, M. and Dowel, N.M. (2017) Bio-Energy with CCS (BECCS) Performance Evaluation: Efficiency Enhancement and Emission Reduction. Applied Energy, 195, 289-302. https://doi.org/10.1016/j.apenergy.2017.03.063 